\title{
An Empirical Inquiry Into The Effectiveness Of The Growth Center Approach To Regional Economic Development\#
}

\author{
Randolph C. Martin*
}

\section{INTRODUCTION}

Over two decades have now elapsed since Perroux [14] introduced the concept of the "growth pole." During this period the policy related notion of selecting "growth centers" for large-scale public investment has received wide attention and has been implemented by many countries, including the United States, as a strategy for promoting growth in backward or underdeveloped regions. In more recent years, many of these countries have either completely abandoned or greatly reduced the emphasis on this approach to regional development. The reason for this diminished emphasis appears to be the lack of success resulting from a tendency toward a proliferation of a large number of relatively small centers incapable of effectively performing the role ascribed to them. ${ }^{1}$ While some scholars have argued that the growth center strategy has not been given enough time to prove its effectiveness, ${ }^{2}$ it would now appear that the concept has lost favor with planners and public officials alike.

In the United States, the basic framework for implementation of a public program for investment in selected growth centers is set out in the Public Works and Economic Development Act of 1965. The legislation created the Economic Development Administration (EDA). It also called for the creation of "economic development districts" and "economic development centers." Development districts are multicounty groupings within which development projects of broad geographic significance are to be planned or carried out. The development centers are communities within the districts and are to be related to the district so that their economic growth may be expected to create more jobs and higher incomes for the population of the surrounding areas. ${ }^{3}$

The major purpose of this paper is to provide some empirical evidence

\footnotetext{
\#This research was partially supported by a grant from the Office of Research, Economic Development Administration, U. S. Department of Commerce. The results and their interpretation do not, however, necessarily reflect the official position of EDA. The author would like to thank Joseph Pelzman, Ronald P. Wilder and Robert E. Graham. Jr. for their helpful comments on a previous draft of this paper.

*Department of Economics, University of South Carolina.
} 
on the effectiveness of EDA dollars spent on projects in development centers in stimulating economic expansion in the surrounding development district counties. To this end, Section II examines the geographic distribution of the funding patterns to both development districts and development centers. Of specific interest here is the extent to which U. S. regional development efforts have actually followed a growth center approach. Section III develops a simple model of county income change which is then used in Section IV to examine (via regression analysis) the relationship between the amount, type, and timing of federal assistance received by development centers and the growth performance of surrounding development district counties. Finally, Section V provides a summary of the empirical results and outlines the implications of these findings.

\section{THE SPATIAL DISTRIBUTION OF AND FUNDING PATTERNS FOR ECONOMIC DEVELOPMENT DISTRICTS}

As noted above, the primary focus of any U. S. growth center program has been with the Economic Development Administration (EDA). ${ }^{4}$ By March 1, 1973 EDA had 128 operating economic development districts (EDDs). Table 1 provides a summary of the regional distribution of these districts and their associated growth centers. ${ }^{5}$ As can be seen, nearly one half of the EDDs are found in the Southeastern States, an area which until recent years could indeed be classified as a "problem area." Also, the information in column (5) shows that this region had by far the largest percentage of its counties contained in designated and operating EDDs $(58 \%)$. For the U. S. as a whole, about one-third of the counties are included in development districts. Turning to the average "size" of these districts, column (6) in Table 1 shows that the average development district in the U. S. contains eight counties. This includes a high of nine counties per district for the Southeast and a low of four counties per district for the Far West.

Finally, columns (7) and (8) provide some information on the number of "economic development centers" (growth centers) associated with the EDDs. The tally is made in terms of the number of counties containing one or more communities specified as development centers. While the vast majority of these counties contained only one growth center, a few (2) were found to include two centers. For simplicity, these counties were counted as containing single centers. As can be seen, 210 counties (or about $7 \%$ of all U. S. counties) contain growth centers. Also, the largest number of these centers are in the Southeast where $12 \%$ of all counties and $21 \%$ of EDD counties contain growth centers.

Given the rather extensive discussion of the appropriate size for growth centers found in the literature, ${ }^{6}$ Table 2 shows the mean 1962 population for all U. S. counties, all EDD counties and all growth center counties. 1962 was selected as the base year since this date marks the beginning of federal regional development efforts under the Area Redevelopment Act(ARA). 
TABLE 1

Geographic Distribution of Economic

Development Districts (EDDs)

$$
1973
$$

\begin{tabular}{|c|c|c|c|c|c|c|c|}
\hline (1) & $\begin{array}{c}(2) \\
\text { number } \\
\text { of } \\
\text { EDDs }\end{array}$ & $\begin{array}{c}\text { (3) } \\
\text { total } \\
\text { number of } \\
\text { counties }\end{array}$ & $\begin{array}{c}\text { (4) } \\
\text { number of } \\
\text { counties } \\
\text { in EDDs }\end{array}$ & $\begin{array}{c}(5) \\
\% \text { of } \\
\text { counties } \\
\text { in EDDs }\end{array}$ & $\begin{array}{c}(6) \\
\text { average \# } \\
\text { of counties } \\
\text { Per EDD }\end{array}$ & $\begin{array}{c}(7) \\
\text { number of } \\
\text { growth center } \\
\text { counties }\end{array}$ & $\begin{array}{l}\quad(8) \\
\% \text { of EDD } \\
\text { counties } \\
\text { with growth } \\
\text { centers }\end{array}$ \\
\hline New England & 3 & 67 & 16 & $24 \%$ & 5 & 6 & $38 \%$ \\
\hline Mideast & 7 & 174 & 43 & $25 \%$ & 6 & 12 & $28 \%$ \\
\hline Great Lakes & 12 & 436 & 93 & $21 \%$ & 8 & 21 & $23 \%$ \\
\hline Plains & 13 & 713 & 89 & $12 \%$ & 7 & 9 & $10 \%$ \\
\hline Southeast & 60 & 927 & 540 & $58 \%$ & 9 & 113 & $21 \%$ \\
\hline Southwest & 17 & 376 & 142 & $38 \%$ & 8 & 28 & $20 \%$ \\
\hline $\begin{array}{l}\text { Rocky } \\
\text { Mountains }\end{array}$ & 9 & 213 & 65 & $31 \%$ & 7 & 11 & $17 \%$ \\
\hline Far West & 7 & 150 & 26 & $17 \%$ & 4 & 10 & $38 \%$ \\
\hline U.S. & 128 & 3056 & 1014 & $33 \%$ & 8 & 210 & $21 \%$ \\
\hline
\end{tabular}

${ }^{1}$ The regional delineation used in this and following tables is that specified by the Bureau of Economic Analysis, U. S.

Department of Commerce. 
TABLE 2

Mean County Population for All U. S. Counties,

All EDD Counties and All Growth Center

Counties: By Region

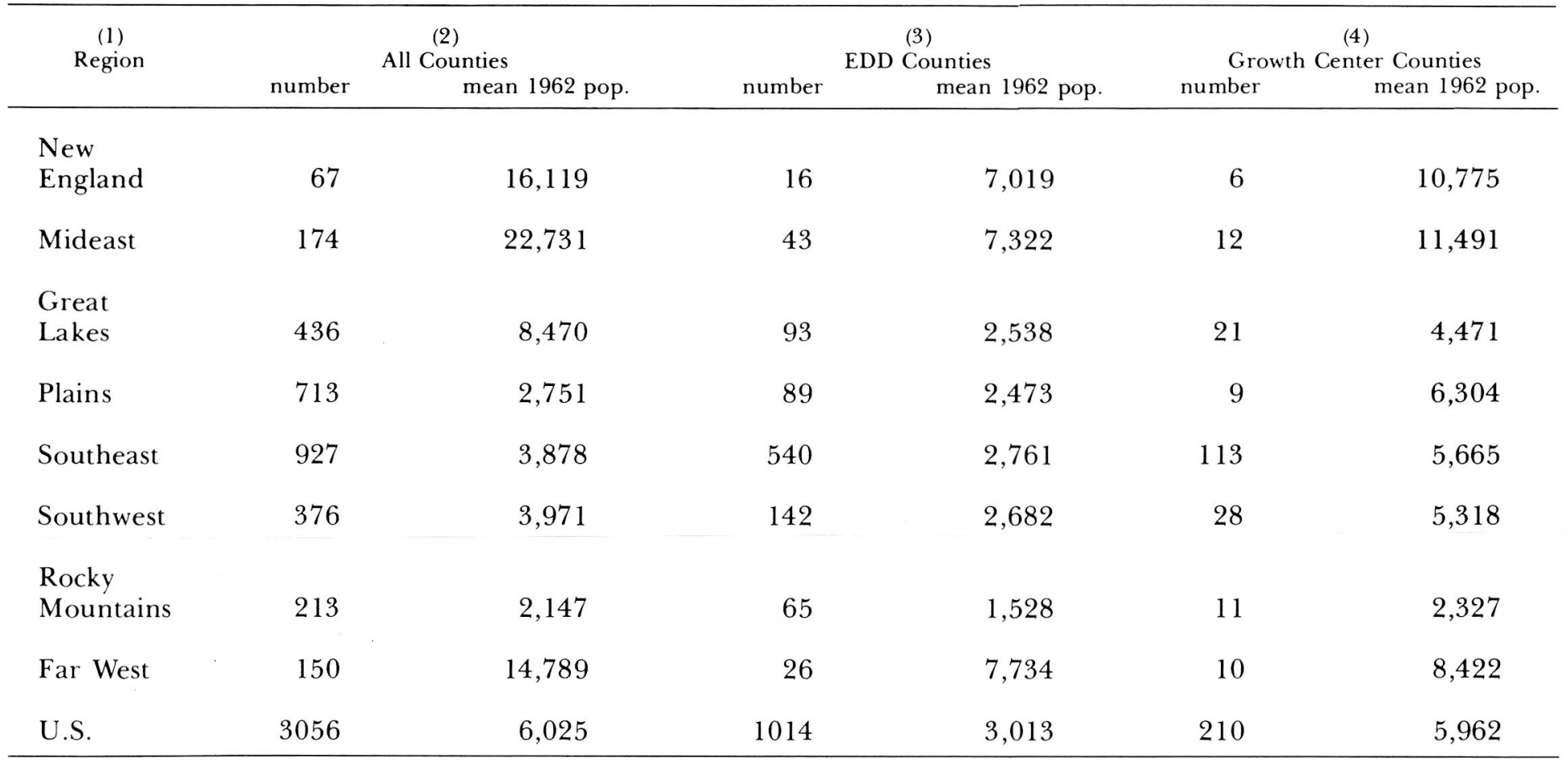


Counties which have since been chosen as containing growth centers had on the average a 1962 population which was roughly twice as large as that found in all EDD counties (5962 vs 3013). However, the mean population of these growth center counties was almost exactly equal to the mean population for all U. S. counties. Only for those centers found in the Plains, Southeast, and Southwest regions is the mean growth center population found to be significantly larger than the mean population for all counties in the region. So, while the growth center counties appear to be certainly more "urbanized" than surrounding development district counties, Table 2 implies relatively small populations nowhere near the minimal level usually considered as being necessary for influencing the welfare of surrounding areas (e.g. 50,000, Hansen [8, p. 74]).

The final concern of this section is with the distribution of federal development assistance to EDDs and growth centers. Utilizing data provided by EDA on annual development disbursements to counties (by program type) over the 1962 to 1974 period, Table 3 provides a regional breakdown of mean county and per capita expenditures over this period to all U. S. counties, EDD non-growth center counties, and growth center counties. It should be noted that over this period, approximately one half (1512) of all U. S. counties received some type of ARA and/or EDA funds. One also observes that a significantly larger percent of EDD counties, excluding growth centers, have received assistance $(73 \%)$. Thus, the data indicate that any growth center notion of withholding aid from hinterland areas and concentrating it in specified centers has not been followed. A larger percentage of "hinterland" counties have received assistance than is found for all U. S. counties. ${ }^{7}$ It is true, however, that an even larger percent $(88 \%)$ of growth center counties have received ARA and/or EDA assistance than have any other group.

Turning to the amount of aid received by the areas shown in Table 3 , one does find some indication of concentrated federal assistance in growth center areas. For example, the mean county aid to all U. S. counties receiving assistance over this period was nearly $\$ 512$ thousand. On the other hand, mean aid to all non-growth center EDD counties was $\$ 442$ thousand while the value for growth center counties was almost twice this amount ( $\$ 860$ thousand). In some regions, this difference is even greater. In the Plains States, the average EDD county received $\$ 284$ thousand while growth center counties have a mean aid value of $\$ 1.2$ million. The smallest regional difference in mean aid between EDD and growth center counties is found for the Southeast, where growth center counties have a mean aid value only $30 \%$ higher than that of EDD counties. Thus in general, a significant difference in mean aid per county exists between EDDs and growth centers.

Using mean per capita aid as a measure of the concentration of assistance presents a somewhat different picture. For all U. S. aided counties, mean per capita aid (using 1962 population) was $\$ 58$. Per capita aid to EDD and growth center counties is found to be significantly higher; $\$ 175$ for EDD counties and $\$ 136$ for growth center counties. The larger values for EDD counties leads to a different conclusion from that reached above concern- 
ing the concentration of federal development effort in growth centers. However, per capita aid to growth center counties exceeds that to "hinterland" counties in the majority of the regions contained in Table 3. Only for the Plains, Great Lakes, and Southeast States does one find higher per capita aid going to non-growth center EDD counties. The U. S. difference undoubtedly reflects the generally larger populations found in the growth center counties.

In summary, the information contained in Tables 1 through 3 indicates a geographically wide spread distribution of the development district concept, with approximately one-third of all counties contained in Economic Development Districts. The average size (population) of the growth centers selected, however, is quite small and well below that usually considered as being appropriate for effective impacts on surrounding areas. Finally, while there is some evidence that federal assistance has been concentrated in these growth centers, the degree of concentration would not imply a strong adherence to the growth center concept.

\section{INCOME GROWTH IN ECONOMIC DEVELOPMENT DISTRICT COUNTIES}

The purpose of this section is to develop a model of county income change which will allow for an assessment of the impact of growth center characteristics on income growth rates in surrounding EDD counties. The model used is one stated in terms of the well known base theory of small area income change. ${ }^{8}$

The traditional approach is to divide county income into its basic and non-basic components. Identity (1) indicates that county income $(\mathrm{Y})$ is made up of income generated by export activities $\left(\mathrm{Y}_{\mathrm{B}}=\right.$ basic income $)$ and income generated by local purchases of locally produced goods and services $\left(\mathrm{Y}_{\mathrm{NB}}=\right.$ nonbasic income $)$.

$$
\text { (1) } Y=Y_{N B}+Y_{B}
$$

It is assumed that the level of nonbasic activity is functionally related to the level of basic activity. This relationship is usually stated in terms of the nonbasic to basic income ratio. Equations (2a) and (2b) reflect these relationships and the t superscripts reflect some given time period.

(2a) $Y_{N B}=f\left(Y_{B}\right)$

(2b) $\mathrm{Y}_{\mathrm{NB}}^{\mathrm{t}}=\left(\mathrm{Y}_{\mathrm{NB}} / \mathrm{Y}_{\mathrm{B}}\right) \mathrm{H}_{\mathrm{B}}^{\mathrm{t}}$

Substituting (2b) into (1) yields

(3) $Y^{t}=\left[1+Y_{N B} / Y_{B}\right] Y_{B}^{t}$. 
TABLE 3

The Geographic Distribution of ARA/EDA Assistance

to All U. S. Counties, EDD non-Growth Center

Counties, and Growth Center Counties 1962-1974

\begin{tabular}{|c|c|c|c|c|c|c|c|c|c|c|c|c|}
\hline \multirow{2}{*}{$\begin{array}{c}(1) \\
\text { Region }\end{array}$} & \multicolumn{4}{|c|}{$\begin{array}{c}(2) \\
\text { All Counties } \\
\end{array}$} & \multicolumn{4}{|c|}{$\begin{array}{c}(3) \\
\text { EDD non-Growth Center Counties }\end{array}$} & \multicolumn{4}{|c|}{$\begin{array}{c}(4) \\
\text { Growth Center Counties }\end{array}$} \\
\hline & $\begin{array}{l}\text { Number } \\
\text { w/Aid }\end{array}$ & $\begin{array}{c}\% \\
\text { Total }\end{array}$ & $\begin{array}{l}\text { Mean Aid } \\
\text { Per County }\end{array}$ & $\begin{array}{l}\text { Mean Per } 1 / \\
\text { Capita Aid }\end{array}$ & $\begin{array}{c}\text { Number } \\
\text { w/Aid }\end{array}$ & $\begin{array}{c}\% \\
\text { Total }\end{array}$ & $\begin{array}{l}\text { Mean Aid } \\
\text { Per County }\end{array}$ & $\begin{array}{l}\text { Mean Per }{ }^{1} \\
\text { Capita Aid }\end{array}$ & $\begin{array}{c}\text { Number } \\
\text { w/Aid }\end{array}$ & $\begin{array}{c}\% \\
\text { Total }\end{array}$ & $\begin{array}{l}\text { Mean Aid } \\
\text { per County }\end{array}$ & $\begin{array}{l}\text { Mean Per }{ }^{1} \\
\text { Capita Aid }\end{array}$ \\
\hline $\begin{array}{l}\text { New } \\
\text { England }\end{array}$ & 55 & $82 \%$ & $\$ 1,169,411$ & $\$ 62$ & 8 & $80 \%$ & $\$ 427,065$ & $\$ 76$ & 6 & $100 \%$ & $\$ 1,271,116$ & $\$ 118$ \\
\hline Midwest & 107 & $61 \%$ & 790,499 & 28 & 21 & $68 \%$ & 586,593 & 78 & 12 & $100 \%$ & $1,416,137$ & 123 \\
\hline $\begin{array}{l}\text { Great } \\
\text { Lakes }\end{array}$ & 197 & $45 \%$ & 408,483 & 32 & 60 & $83 \%$ & 475,867 & 216 & 19 & $90 \%$ & 645,013 & 142 \\
\hline Plains & 173 & $24 \%$ & 242,866 & 43 & 43 & $54 \%$ & 284,251 & 112 & 8 & $89 \%$ & $1,206,901$ & 178 \\
\hline Southeast & 613 & $66 \%$ & 500,840 & 122 & 329 & $77 \%$ & 453,480 & 215 & 96 & $85 \%$ & 597,214 & 98 \\
\hline Southwest & 173 & $46 \%$ & 462,966 & 72 & 86 & $75 \%$ & 350,002 & 162 & 25 & $89 \%$ & $1,124,696$ & 205 \\
\hline $\begin{array}{l}\text { Rocky } \\
\text { Mountains }\end{array}$ & 96 & $45 \%$ & 321,317 & 106 & 31 & $57 \%$ & 338,080 & 195 & 10 & $91 \%$ & 632,151 & 251 \\
\hline Far West & 98 & $65 \%$ & 859,787 & 42 & 11 & $69 \%$ & $1,387,084$ & 133 & 9 & $90 \%$ & $2,300,732$ & 253 \\
\hline U. S. & 1512 & $49 \%$ & 511,641 & 58 & 589 & $73 \%$ & 442,213 & 175 & 185 & $88 \%$ & 859,507 & 136 \\
\hline
\end{tabular}

${ }^{1}$ Using 1962 population 
Taking the total differential of (3) and dividing through by $\mathrm{Y}^{\mathrm{t}}$ then gives

(4) $d Y / Y^{t}=\left[1+Y_{N B} / Y_{B}\right] d Y_{B} / Y^{t}$.

So, relative changes (growth) in county income from period $t$ are viewed to be dependent upon the assumed constant nonbasic to basic income ratio and relative changes in basic income. The former generates the so-called economic base multiplier $\left[1+\mathrm{Y}_{\mathrm{NB}} / \mathrm{Y}_{\mathrm{B}}\right]$ and the later reflects exogenous changes in basic income resulting from the area's export activities.

This simple model can then provide the analytical framework for assessing the role of federal aid to growth centers in stimulating economic expansion in surrounding development district counties. For example, changes in basic income $\left(\mathrm{dY}_{\mathrm{B}} / \mathrm{Y}^{\mathrm{t}}\right)$ can be divided into: $\left.\mathrm{a}\right)$ changes generated by federal development expenditures and 2) changes generated by other exogenous factors. Thus:

(5) $\mathrm{dY}_{\mathrm{B}} / \mathrm{Y}^{\mathrm{t}}=\left(\mathrm{X}_{\mathrm{j}}+\mathrm{Z}_{\mathrm{i}}\right) / \mathrm{Y}^{\mathrm{t}}$

where $X_{j}=$ a vector of changes in basic income resulting from $j$ factors related to EDA programs.

$Z_{i}=$ a vector of changes in basic income resulting from i nonEDA related factors.

Since we have already observed that many non-growth center development district counties have been the recipient of EDA funds, it is necessary to separate this potential effect on basic income from the potential contribution of growth center programs to EDD county income change. We might then state that:

(6) $X_{j}=A_{k}+B_{1}$

where $A_{k}=$ a vector of changes in EDD county basic income resulting from $\mathrm{k}$ factors associated with EDA programs carried out within the county.

$\mathrm{B}_{1}=\mathrm{a}$ vector of changes in EDD county basic income resulting from 1 factors associated with EDA programs carried out in growth center counties.

with $\mathrm{j}=\mathrm{k}+\mathrm{l}$.

Taking the preceding considerations into account and substituting (5) and (6) into equation (4) yields

(7) $\mathrm{dY} / \mathrm{Y}^{\mathrm{t}}=\left[1+\mathrm{Y}_{\mathrm{NB}} / \mathrm{Y}_{\mathrm{B}}\right]\left(\mathrm{A}_{\mathrm{k}}+\mathrm{B}_{1}+\mathrm{Z}_{\mathrm{i}}\right) / \mathrm{Y}^{\mathrm{t}}$

In other words, relative changes in income for a county are viewed to be 
dependent upon the county's economic base multiplier $\left[1+\mathrm{Y}_{\mathrm{NB}} / \mathrm{Y}_{\mathrm{B}}\right]$, a set of factors related to EDA expenditures in that county $\left(\hat{\mathrm{A}}_{\mathrm{k}}\right)$, a set of factors related to EDA expenditures in an associated growth center county $\left(\mathrm{B}_{1}\right)$, and set of factors related to other exogenous influences $\left(\mathrm{Z}_{\mathrm{i}}\right)$.

The size of a county's economic base multiplier depends upon the relationship between basic and nonbasic activity found in the county. While a precise estimation of such a value creates certain measurement problems, ${ }^{9}$ it is a rather simple task to develop a useable proxy variable and this is done below. The more difficult task is the identification of various factors (both EDA and non-EDA related) which could generate changes in basic income and thus, multiple changes in total area income. It is this subject to which we now turn.

Looking first at non-EDA related factors, one might begin by stating that improved county income growth rates between any two periods may reflect differences in national or regional demand levels existing during the two periods. Given demand conditions during some "pre-federal aid period," improvements in basic income growth rates (and thus total income growth rates) over the "aid period" could reflect improvements in the overall demand for the county's exports. Secondly, changes in the composition of the demand for a county's exports can be expected to influence county income growth rates. Given a county's economic structure, an acceleration in personal income growth rates might represent an exogenous shift in national or regional demand in favor of a dominant export industry. Thus, the larger the representation of nationally expanding firms found in a county, the greater is the expected growth in basic and total personal income. ${ }^{10}$ As a third possible factor, growth in county export activities could reflect the fact that local representatives of any particular industry group have been successful in capturing a larger share of national or regional markets. This may represent some newly acquired comparative advantage in the production and/or distribution of the product.

A final non-EDA related potential contributor to changes in county growth rates is the level of area resource utilization at the beginning of the period being considered. If one assumes a high degree of factor mobility between sectors within an area, an exogenous increase in demand for a county's exports will be translated into greater employment levels and higher aggregate income if the county had a large percent of its resources being initially unemployed (i.e. - as the unemployed resources return to productive use). If, on the other hand, high unemployment rates are reflective of the lack of factor mobility in an area (e.g. - structural unemployment), increases in demand for exports may not be as effectively translated into higher employment levels and income growth rates. ${ }^{11}$ Thus, while the direction of the relationship between levels of resource utilization and future income growth may be difficult to anticipate on $a$ priori grounds, one would expect this to be an important non-EDA factor relating to changes in county income growth rates.

The above discussion has centered on factors not associated with federal development programs. We now turn to a consideration of the role of federal development expenditures. Concern will be given to expenditures 
in the development district counties and expenditures in their associated growth centers. The view taken is quite simple in that development expenditures are considered as another exogenous influence on levels of basic income.

The amount of change in basic income generated by EDA expenditures within a particular county would depend first, and most obviously, upon the amount of aid received. The more assistance received (relative to its economic size) the greater is the expected change in relative basic income. Also, given the amount of aid received, different types of developmental programs may have differing effects on basic income. ${ }^{12}$ Finally, the timing of EDA expenditures in a county over the period of aid could very likely influence measured changes in income growth. That is, given the length of the aid period and the a mount of aid received, the fact that the bulk of the assistance came early or late in the period may result in differing impacts on income growth rates over the period of concern.

Turning to the role of federal aid in growth centers and the expected influences on income changes in surrounding development district counties, we might first suggest that the larger the relative amount of aid given to the growth center county, the greater is the expected influence on hinterland areas. Increases in growth center income resulting from this aid will generate increased demand for the resources and products of surrounding counties leading to an expansion in their growth rates. ${ }^{13} \mathrm{It}$ further follows that if different development program types have differing effects on recipient county incomes, then these differences will be transmitted to surrounding areas. The same can be said for the timing of aid received by these growth center counties.

The above discussion of potential EDA and non-EDA factors expected to influence changes in county income growth rates represents hypotheses which lend themselves to empirical testing. The next task is to specify an empirically testable reduced form model based on equation (7) and the implications outlined above. Of specific interest is whether or not the amount, nature and timing of federal aid to growth center counties has had a significant influence on changes in growth rates of surrounding EDD counties once other growth influencing factors have been accounted for.

\section{SOME EMPIRICAL RESULTS}

Equation (7) and the discussion found in the preceding section imply that changes in a development district county's income growth rate depends upon the county's economic base multiplier, a set of non-EDA related factors, and EDA activities carried out in both growth centers and the county itself. This can be written in the implicit form:

(8) $\mathrm{CHNGR}=\mathrm{f}\left(\mathrm{MULT}, \mathrm{NEDA}_{1} \ldots \mathrm{NEDA}_{\mathrm{i}}, \mathrm{EDA}_{1} \ldots \mathrm{EDA}_{\mathrm{k}}\right.$, $\left.\operatorname{GCEDA}_{1} \ldots \mathrm{GCEDA}_{1}\right)$ 
where

CHNGR = change in compound annual growth rates in personal income between any two periods.

MULT = economic base multiplier.

$\mathrm{NEDA}_{1} \ldots \mathrm{NEDA}_{\mathrm{i}}=$ a set $\mathrm{i}$ exogenous factors unrelated to EDA programs which are hypothesized to influence changes in county income growth rates

$\mathrm{EDA}_{1} \ldots \mathrm{EDA}_{\mathrm{k}}=$ a set of $\mathrm{k}$ factors relating to EDA programs carried out within the county.

$\mathrm{GCEDA}_{1} \ldots \mathrm{GCEDA}_{1}=$ a set of 1 factors relating to growth center characteristics and EDA program carried out in these centers.

In order to estimate the effect of EDA activities in growth center counties on surrounding development district counties, a set of proxy variables was defined for each of the potential source of income change. Using these variables and their values for all non-growth center development district counties, the following model was estimated using ordinary least squares.

(9) CHNGR $=$ (MULT NAIDCH PERMAN PERMIN PERGOV SHARE RELUN RELLAG RELAID PERPW TIME GCAID GCPW GCTIME)

The dependent variable is defined as

$\mathrm{CHNGR}=$ (Compound annual growth rate of total personal income [TPI] from 1962 to 1974 ) - (compound annual growth rate of TPI from 1950 to 1962$){ }^{\mathbf{1 4}}$

The first eight independent variables are intended to reflect the economic base multiplier and the previously discussed non-EDA contributors to income change. Their values and expected influence on CHNGR are:

MULT $=(1+$ nonbasic income/basic income $)$. Using 1965 data, the earliest year for which county income by source was available, basic income was defined to include income derived from agriculture, manufacturing, mining, and that portion (if any) of government-generated income above the average government income to total income relationship for the U.S. Nonbasic income is that derived from all other sources. It is expected that ceteris paribus, there will be a direct and significant relationship between MULT and CHNGR. ${ }^{15}$

NAIDCH $=$ (compound annual growth rate of TPI for all non-aided 
counties in the county's region from 1962 to 1974) - (compound annual growth rate of TPI for all non-aided counties in the county's region from 1950 to 1962). This variable is intended to control for regional demand levels over the periods of comparison. Again, a direct relationship with CHNGR is expected.

PERMAN, PERMIN, PERGOV = (percent of 1965 basic income in the county derived from manufacturing, mining, and government respectively). These variables control for the effect of industry mix on changes in county grow th rates. The influence of the sector omitted (agriculture) will be included in the intercept term when equation (9) is estimated.

SHARE $=[($ GRAG/USGRAG $)+($ GRMN/USGRMN $)+($ GRMI USGRMI $)+($ GRGV/USGRGV $)]$ where GRAG, GRMN, and GRV equal the annual growth rates (1962-1974) in county income derived from agriculture, manufacturing, mining and basic government respectively. USGRAG, USGRMN, USGRMI and USGRGV are measures of annual U.S. income growth rates over the same period from the four sources of basic income. This variable generates an index of the relative performance of a county's basic industries over the period. If a county has firms in the basic industry groups which have expanded more rapidly than the national average for these groups, SHARE will assume a relatively large value. A positive relationship between this variable and CHNGR is expected. ${ }^{16}$

RELUN $=(1960$ unemployment rate for county $\div$ mean 1960 unemployment rate for all U. S. counties). This variable is intended to reflect the relative pre-aid level of resource utilization for the county. Given the discussion in the previous section, no a priori expectation exists concerning the relationship between RELUN and CHNGR.

RELLAG $=$ (growth rate in county income, $1950-1962 \div$ growth rate in all non-aided counties in the region, 1950-1962). Relative pre-aid growth rates are reflected by this variable. Given the general expansionary conditions existing over most of the 1960's it might be expected that irrespective of development programs, areas which grew slowly over the 1950 period would expand more rapidly during the next decade. Thus, an inverse relationship with CHNGR is expected.

The next three independent variables in equation (9) are reflective of EDA programs carried out within the EDD county. They are designed to measure the relative amount, nature and timing of EDA assistance going directly to the county. Variables and hy potheses concerning their influence on county income growth are:

RELAID $=$ (total dollar dispersements to the county $\div 1962$ population). This is a measure of per capita aid and it is expected that, ceteris paribus, the larger the amount of relative aid received (RELAID), the greater will be the change in county growth rates (CHNGR). 
PERPW $=$ (percent of total disbursements going to public works projects). This variable is a gross measure of the mix of program types which have been implemented in the county. There exists no a priori expection about the relationship between this variable and CHNGR.

$$
\begin{aligned}
& \text { TIME }=(3 \times[\mathrm{D} 62+\mathrm{D} 63+\mathrm{D} 64+\mathrm{D} 65]+2 \times[\mathrm{D} 66+\mathrm{D} 67+\mathrm{D} 68 \\
&+\mathrm{D} 69]+[\mathrm{D} 70+\mathrm{D} 71+\mathrm{D} 72+\mathrm{D} 73+\mathrm{D} 74])
\end{aligned}
$$

where D62, D63 ... D74 equal annual aid disbursements to the county for 1962, $1963 \ldots 1974$. This variable reflects the timing of EDA assistance, giving greater weight to aid received in the early years of the program. If a county received no aid this and the above variables will have zero values. Again, there exists no a priori expection concerning the relationship between this variable and CHNGR.

The remaining three independent variables relate to EDA activities carried out in the growth center county(ies) associated with each nongrowth center development district county.

GCAID = (average per capita aid going to the growth center county(ies) contained in a county's EDD). This variable reflects the amount of aid going to the growth center(s) associated with each county. The hypothesis tested with this variable is whether or not a larger amount of aid going to growth centers is associated with expanded income growth in EDD counties.

GCPW $=$ (average percent of growth center aid associated with public works). Here, if public works projects in growth centers generate a greater increase in EDD county income, then a positive association with CHNGR will be found.

GCTIME = (average value of TIME for growth center county(ies) contained in a county's EDD). With the above definition of TIME, this variable reflects the timing of aid going to an EDD county's growth center(s). As before, no specific relationship between this variable and CHNGR is suggested.

The results of estimating equation (9) for all non-growth center EDD counties are shown in Table 4. Column (1) presents coefficients and t values associated with a regression where CHNGR is run on the non-EDA related variables alone. These results are basically consistent with the above suggested hypotheses. Coefficients for MULT, NAIDCH, SHARE, and RELLAG all have the expected signs and found to be significantly different from zero at normal acceptance levels. The coefficients for the industry mix variables (PERMAN, PERMIN, PERGOV) indicate that counties whose basic industrial mix is dominated by manufacturing and government activities experienced relatively larger increases in income growth rates. Also, the negative and significant unemployment coefficient (RELUN) implies that perhaps the local labor supply in high unemployment 
counties is not very adaptable to changes resulting from increased demand for the areas exports. Finally, an $\mathrm{R}^{2}$ of .52 is quite respectable given the cross-section nature of this estimate. It would thus appear that the economic base model is an adequate vehicle for analyzing the influence of EDA activities on this group of EDD counties.

The second column in Table 4 contains the regression results when the EDA-related program variables associated with developmental activities carried out within EDD counties are included. First, the per capita aid variable (RELAID) exhibits a positive and different from zero influence on changes in county growth rates. A similar observation is possible for the type of aid (PERPW) and timing of aid (TIME) although here the null hypotheses can be rejected only at the $10 \%$ level. This implies that counties which received predominately public works aid and received it early in the aid period, certeris paribus, tend to experience larger increases in income growth rates.

The last column in Table 4 contains the coefficients and t values when all variables of equation (9) are included in the regression. The last three variables (GCAID, GCPW, GCTIME) are associated with EDA activities in growth center counties. Inclusion of these variables will reflect the effect of EDA aid to growth center counties on growth rate changes in surrounding EDD counties. As can be seen, the amount of per capita aid received by growth centers (GCAID) does have an effect on CHNGR which is positive and different from zero. Also, the positive and significant coefficient associated with GCPW indicates that public works activities in growth center counties tend to have a more expansionary impact on surrounding EDD counties than do other types of EDA projects. This is consistent with the observation that public works projects within EDD counties are more expansionary than other program types. Finally, it appears that the timing of aid to growth centers is not an important factor in explaining variations in growth rate changes for EDD counties.

While the above findings indicate that certain EDA program variables have significantly different from zero effects on CHNGR, there remains the question of the magnitude of these effects. To shed some light on this, Figure 1 shows the results of a simple simulation experiment involving two of the major EDA program variables. First, the actual range of observed values for CHNGR is shown $(-.098$ to +.129$) .{ }^{17} \mathrm{Next}$, using the regression coefficients from column 3 of Table 4 and the mean values for the independent variables, simulated values of CHNGR are generated. This is done first using the minimum $(0)$ and then the maximum $(\$ 27.7)$ values observed for GCAID (per capita aid to growth center county) and the mean values for all other independent variables. As shown, this yields a simulated range for C.HNGR of .045 to 058 implying that $\$ 28$ in per capita aid for growth centers would, on average, result in a 1.3 percentage point improvement in income growth rates for surrounding EDD counties. A similar simulation is shown for RELAID (per capita aid to non-growth center EDD counties). The range of observed values for this variable is 0 to $\$ 45.1$ and using these, estimates of CHNGR are found to be .044 and .062 . respectively: Thus, the implication is that ceteris paribus, a $\$ 45$ per capita 
TABLE 4

Changes In Total Personal Income Growth Rates

For Economic Development District Counties

(Dependent Variable $=\mathrm{CHNGR}$ )

\begin{tabular}{|c|c|c|c|}
\hline $\begin{array}{l}\text { Dependent } \\
\text { Variable }\end{array}$ & (1) & (2) & (3) \\
\hline Intercept & $\begin{array}{l}.059^{* * *} \\
(16.29)\end{array}$ & $\begin{array}{l}.057 * * * \\
(15.41)\end{array}$ & $\begin{array}{l}.053^{* * *} \\
(13.04)\end{array}$ \\
\hline MULT & $\begin{array}{c}.002 * * * \\
(3.20)\end{array}$ & $\begin{array}{c}.002 * * * \\
(3.08)\end{array}$ & $\begin{array}{l}.001 * * * \\
(2.70)\end{array}$ \\
\hline NAIDCH & $\begin{array}{c}.689 * * * \\
(8.12)\end{array}$ & $\begin{array}{c}.675^{* * * *} \\
(8.01)\end{array}$ & $\begin{array}{l}.702 * * * \\
(8.10)\end{array}$ \\
\hline PERMAN & $\begin{array}{c}.007 * * * \\
(2.89)\end{array}$ & $\begin{array}{c}.007 * * * \\
(2.77)\end{array}$ & $\begin{array}{l}.007 * * * \\
(2.82)\end{array}$ \\
\hline PERMIN & $\begin{array}{l}.001 \\
(.33)\end{array}$ & $\begin{array}{l}.002 \\
(.45)\end{array}$ & $\begin{array}{l}.001 \\
(.20)\end{array}$ \\
\hline PERGOV & $\begin{array}{l}.014 * * * \\
(2.88)\end{array}$ & $\begin{array}{l}.014 * * * \\
(2.94)\end{array}$ & $\begin{array}{c}.014 * * * \\
(2.92)\end{array}$ \\
\hline SHARE & $\begin{array}{c}.0001^{* *} \\
(2.14)\end{array}$ & $\begin{array}{c}.0001 * * \\
(2.13)\end{array}$ & $\begin{array}{l}.0001^{* *} \\
(2.19)\end{array}$ \\
\hline RELUN & $\begin{array}{c}-.004 * * * \\
(-2.58)\end{array}$ & $\begin{array}{c}-.005^{* * *} \\
(-3.33)\end{array}$ & $\begin{array}{c}-.004 * * * \\
(-3.03)\end{array}$ \\
\hline RELLAG & $\begin{array}{l}-.056 * * * \\
(-27.53)\end{array}$ & $\begin{array}{l}-.055^{* * *} \\
(-27.36)\end{array}$ & $\begin{array}{l}-.056^{* * *} \\
(-27.27)\end{array}$ \\
\hline RELAID & - & $\begin{array}{c}.0004 * * \\
(2.12)\end{array}$ & $\begin{array}{c}.0004^{* *} \\
(2.06)\end{array}$ \\
\hline PERPW & - & $\begin{array}{l}.003^{*} \\
(1.83)\end{array}$ & $\begin{array}{l}.002 \\
(1.37)\end{array}$ \\
\hline TIME & - & $\begin{array}{l}.002 * \\
(1.84)\end{array}$ & $\begin{array}{c}.002^{*} \\
(1.90)\end{array}$ \\
\hline GCAID & - & - & $\begin{array}{r}.002 * * \\
(2.04)\end{array}$ \\
\hline GCPW & - & - & $\begin{array}{c}.010^{* * * *} \\
(2.93)\end{array}$ \\
\hline GCTIME & - & - & $\begin{array}{l}-.002 \\
(-1.08)\end{array}$ \\
\hline $\mathrm{R}^{2}$ & .52 & .53 & .54 \\
\hline
\end{tabular}

$\mathrm{t}$ values in parentheses

*** significant at $1 \%$ level

** significant at $5 \%$ level

* significant at $10 \%$ level 
expenditure by EDA within a EDD county will yield, on the average, a 1.8 percentage point increase in personal income growth rates.

Finally, since the simulated ranges of CHNGR shown in Figure 1 are quite small relative to the actual range, it is of interest to determine the relative explanatory contribution of each of the independent variables to variations in CHNGR. To this end, beta coefficients (Goldburger [6, pp. 197-198]) were calculated for all the independent variables used in the regression shown in column 3 of Table 4 . These beta coefficients, shown in Table 5, give an indication of the importance of each regressor in its individual contribution to the calculated values of CHNGR. As can be seen, the main explanatory contributions are made by the relative pre-aid growth rate (RELLAG) and regional demand (NAIDGR) variables. The largest individual contribution coming from the EDA program variables is associated with the growth center public works variable (GCPW). It is of interest to note that the beta coefficients for the major growth center program variables (GCAID, GCPW) are marginally greater than those found for the program variables associated with aid directly to EDD counties (RELAID, PERPW). Overall, the size of the contribution coming from the individual program variables is small relative to RELLAG and NAIDCH but comparable to the multiplier (MULT) and certain other non-EDA variables.

\section{SUMMARY AND CONCLUSIONS}

This paper began by documenting the notion that the application of a growth center policy in the U.S. has involved the designation of a large number of relatively small communities as growth centers. It also observed that the concept has had a geographically widespread application, with one-third of all U.S. counties contained in Economic Development Districts. Information on how EDA has allocated developmental aid to these areas provides some evidence that assistance has been concentrated in growth center counties but indicates that surrounding counties have also received a significant amount of assistance.

Using an economic base model, the relationships between EDA activities carried on both within EDD counties and within related growth center counties and changes in personal income growth rates for EDD counties were examined empirically. The results imply that the amount and type of assistance given both to the county itself and its growth center has a significant influence on income growth rate changes. Further analysis indicates that the size of these effects may be small relative to other contributing factors.

These observations lead to several conclusions. First, in a statistical sense at least, it would appear that federally supported projects in growth centers do have the desired influence on surrounding areas. Although the effect may be relatively small, it is not possible to conclude that these activities do not have the intended influence. Second, the observed relationship between development dollars for public works (both in EDD counties and growth center counties) and income growth rate changes 
Actual and Simulated Range of CHNGR Values Using Minimum and Maximum Values of GCAID and RELAID

(Using Equation 9)

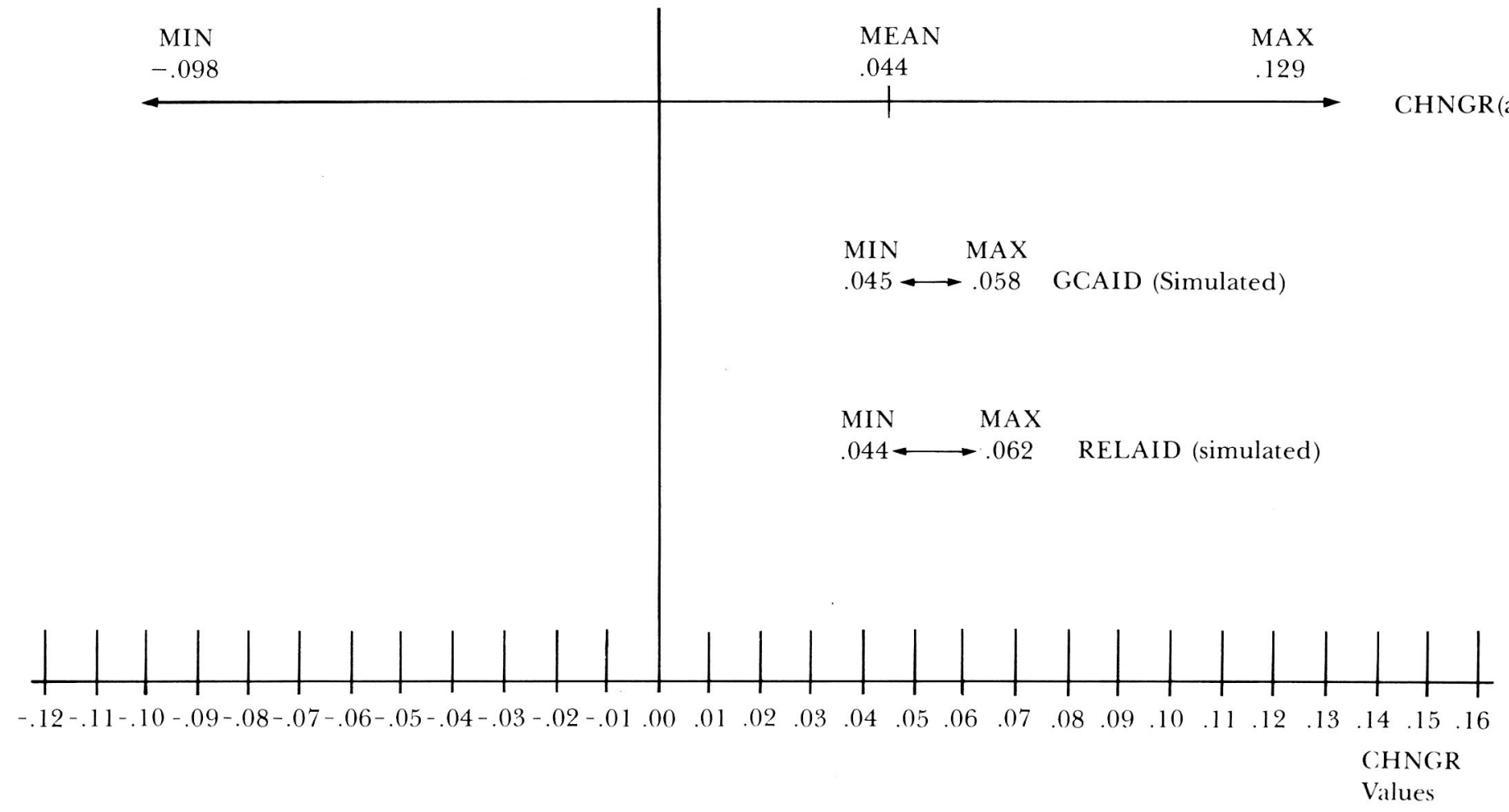


TABLE 5

Beta Coefficients For Independent Variables

\begin{tabular}{lllc}
\hline Variable & $\beta$ Coefficient & Variable & $\beta$ Coefficient \\
\hline MULT & +.098 & RELLAG & -.740 \\
NAIDCH & +.208 & RELAID & +.053 \\
PERMAN & +.082 & PERPW & +.037 \\
PERMIN & +.006 & TIME & +.052 \\
PERGOV & +.078 & GCAID & +.085 \\
SHARE & +.053 & GCPW & +.118 \\
RELUN & -.076 & GCTIME & -.035 \\
\hline
\end{tabular}
imply that the historic preference for public works projects in the federal
regional development effort has not been a misplaced emphasis.

\section{FOOTNOTES}

${ }^{1}$ See Hansen [9, pp. 21-24] and Conroy [4]. Since the growth center concept has been discussed at great length in the literature, the reader will not be subjected to yet another rehash of this material. Cameron [2] and Cameron [3] provide a good overview of the arguments favoring spatially concentrated development spending.

${ }^{2}$ See for example the very convincing analysis provided by Richardson [16].

${ }^{3}$ Title V, Part B of the Public Works and Economic Development Act of 1965 [14].

${ }^{4}$ This excludes the programs and activities of the Title V Regional Development Commissions.

${ }^{5}$ The information for Table 1 was taken from Economic Development Administration [5].

${ }^{6}$ See for example Berry [1], Cameron [3], Hale [7], Hansen [8, 1970] and Morrill [12].

${ }^{7}$ The difficulty of withholding aid from areas that qualify for such assistance is apparent. Any area which qualifies is motivated to apply for EDA assistance since it receives most of the benefits and pays only a small amount of the tax costs. See Moomaw [11] p. 101.

${ }^{8}$ Economic base theory has been criticized for use in explaining long-run secular growth patterns for regions (see Tiebout [17]). However, for shorter-term movements in economic activity and for areas as small as those to be used in this study, the drawbacks are probably less severe (Richardson [15], p. 278).

${ }^{9}$ See Leven [10].

${ }^{10}$ For example, the dramatic improvement in agricultural prices during the early 1970 's undoubtably stimulated the expansion of personal income in counties dominated by farming.
${ }^{11}$ This represents a relative short-run view of resource markets in that it ignores the longer term response of resource in-migration to the area.

${ }^{12}$ The dominate types of EDA programs have been: 1) financial aid (loans and grants) to help communities develop the public facilities needed to attract business; and 2) long-term loans at low rates of interest to provide the capital to attract new business to depressed areas and to help establish firms expand. [3].

${ }^{13}$ See the discussion in Cameron [2] and Cameron

${ }^{14}$ The source of the county income data by industry was the Bureau of Economic Analysis, U.S. Department of Commerce.

${ }^{15}$ While economic base analysis is sensitive to the level of industry aggregation and the geographic size of the community, the basic/non basic definitions used here are reasonable given that counties are used as the unit of observation and that empirical estimation of the relationships is made using a large scale cross section approach.

${ }^{16}$ County data on income by major source was only available from 1965 on at the time this work was done. 1962 values were estimated by calculating the ratios of 1965 county income for each basic income source to the total 1965 income level and multiplying these ratios times the 1962 income level.

${ }^{17}$ The mean value of CHNGR is .044 with a standard deviation of .027 .

\section{REFERENCES}

1. Berry, Brian J.L., "Growth Centers and Their Potentials in the Upper Great Lakes Region" in Industrial Location Potentials, House Committee Hearings, Y4, B22/1: In 2/pt3, May 1969.
2. Cameron, Gordon C., Regional Economic Development: The Federal Role, Resources for the Future, Johns Hopkins Press, Baltimore, 1970a. 
$3 . \quad$ "Growth Areas, Growth Centers and Regional Conversion" Scottish Journal of Political Economy, Vol. 17, Number 1. Feb. 1970b.

4. Conroy, Michael E., "Rejection of Growth Center Strategy in Latin American Regional Development Planning" Land Economics, Vol. 49, Number 4, Nov. 1973.

5. Economic Development Administration. Economic Development Districts, March 1, 1973, map, U.S. Government Printing Office, 1973.

6. Goldberger, A.S., Econometric Theory, John Wiley and Sons, Inc., New York, N.Y. 1964.

7. Hale, Carl W., "Growth Centers, Regional Spread Effects, and National Economic Growth" Journal of Economics and Business, Vol. 26, Number 1, Fall 1973.

8. Hansen, Niles M., "Efficient Regional Resource Allocation and Growth Center Policy" in J.H.P. Paelinck (ed.) Programming for Europe's Collective Needs, American Elsevier Publishing Company, New York, 1970.

9.

Public Policy and Regional Economic Development, Ballinger Publishing Company, Cambridge, MA, 1974.
10. Leven, Charles L., "An Appropriate Unit for Measuring the Urban Economic Base," Land Economics, November, 1974

11. Moomaw, Ronald, "Regional Development Programs: A Critical View" Review of Regional Studies Vol. 1, Number 2, Winter 1970-71.

12. Morrill, Richard L., "On the Size and Spacing of Growth Centers," Growth and Change, Vol. 4, Number 2, April 1973.

13. Perroux, F., "Economics Space: Theory and Application," Quarterly Journal of Economics Vol. 64, 1950.

14. Public Works and Economic Development Act of 1965, As Amended, P.L. 89-136; 42 USC 3121 et seq.

15. Richardson, Harry W., Regional Economics: Location Theory, Urban Structure, Regional Change, Praeger Publishers, New York, NY 1969.

16. _ "Growth Pole Spillovers: The Dynamics of Backwash and Spread," Regional Studies, Vol. 10, Number 1, 1976.

17. Tiebout, Charles M., "Exports and Regional Growth" Journal of Political Economy, Vol. 64, April 1956. 